\title{
Experimental determination of the flood wave transformation and the sediment resuspension in a small regulated stream in an agricultural catchment
}

\author{
David Zumr $^{1}$, Tomáš Dostál ${ }^{1}$, Jan Devátý ${ }^{1}$, Petr Valenta ${ }^{1}$, Pavel Rosendorf $^{2}$, Alexander Eder $^{3}$, and Peter Strauss ${ }^{3}$ \\ ${ }^{1}$ Faculty of Civil Engineering, Czech Technical University in Prague, Prague, 16629, Czech Republic \\ ${ }^{2}$ T. G. Masaryk Water Research Institute, Prague, 16000, Czech Republic \\ ${ }^{3}$ Institute for Land \& Water Management Research, Federal Agency for Water Management, 3252 Petzenkirchen, Austria
}

Correspondence to: David Zumr (david.zumr@fsv.cvut.cz)

Received: 5 May 2017 - Discussion started: 6 June 2017

Revised: 5 September 2017 - Accepted: 25 September 2017 - Published: 16 November 2017

\begin{abstract}
This paper presents the methodology used for artificial flood experiments conducted in a small artificial, trained (regulated) channel on the Nučice experimental agricultural catchment $\left(0.5 \mathrm{~km}^{2}\right)$, central Czech Republic, and the results of the experiments. The aim was to monitor the transformation of the flood wave and the sediment transport within the channel. Two series of experiments were carried out in contrasting initial conditions: (a) in September, when the stream banks were dry, the baseflow was negligible, and the channel was fully overgrown with vegetation; and (b) in March, when the stream banks were almost water saturated, the baseflow was above the annual average, and there was no vegetation present. Within each campaign, three successive flood waves, each with an approximate volume of $17 \mathrm{~m}^{3}$ and peak flow of ca. $40 \mathrm{~L} \mathrm{~s}^{-1}$, were pumped into the upper part of the catchment drainage channel. The transformation of the flood wave and the sediment transport regime within an approximately $400 \mathrm{~m}$ long channel section were monitored by measuring the discharge, the turbidity, and the electrical conductivity in three profiles along the stream. On the basis of the results, it was concluded that there is a considerable amount of deposited sediment, even in the well-trained and straight channel that can be re-mobilized by small floods. Part of the recorded sediment therefore originates from the particles deposited during previous soil erosion events. The flood waves initiated in dissimilar instream conditions progressed differently - we show that the saturation of the channel banks, the stream vegetation and the actual baseflow had a strong influence on the flood transformation and the sediment regime in the channel. The sediment moves quickly
\end{abstract}

in winter and early spring, but in the later part of the year the channel serves as a sediment trap and the resuspension is slower, if dense vegetation is present.

\section{Introduction}

Excessive soil erosion from upland areas resulting in the transport of soil particles with bound organic matter, nutrients, microbes, or pollutants into the rivers and reservoirs is considered as a major environmental problem (Drummond et al., 2014; Lal et al., 2007; Pimentel et al., 1995; Stoate et al., 2001). The processes of soil particle mobilization and transportation within agriculturally used fields, including the transfer into streams and rivers, have been extensively studied (Báčová and Krása, 2016; Boardman, 2003; Lal, 1998; Neal and Anders, 2015).

The headwater streams and drainage channels in sediment source areas, typically small rural catchments with intensively cultivated soils, have considerable retention capacities for sediment and nutrients (Hession et al., 2003). The streams are narrow with a small flow profile, the baseflow is usually low, the stream bed contains fine-grained particles with a high concentration of nutrients, and extensive vegetation can therefore often be found there. Soil particles that enter the channel during an erosion event can easily get embedded in the channel bed alluvium and be remobilized during subsequent runoff events, and the nutrients tend to be retained (Withers and Jarvie, 2008). The source of the sediment and 
the processes related to the suspended sediment dynamics in the closing profiles are therefore of fundamental importance for an assessment of the sediment budget and the transport of dissolved or absorbed substances in the catchment (Walling, 2005). However, even physically based mathematical models of soil erosion assume that the sediment transported through water courses originates from a recent (or current) rainfallrunoff event. Similarly, traditional experiments and soil erosion monitoring usually rely on measurements of the sediment yield at the catchment outlet, assuming that the measured sediment yield originates on the hillslopes. If any retention in the channel is expected, no resuspension is then assumed, and this affects the total sediment budget. Minella et al. (2008) point out that the transport capacity of the channel may increase, and that the stream bed sediment is easily mobilized during runoff events with no eroded sediment from the catchment. Zumr et al. (2015) and also Musolff et al. (2015) show that a quick runoff response with no soil erosion on the fields is very commonly observed on cultivated catchments where subsurface runoff or tile drains are the dominant controls. The resuspension regime of the stream bed sediment and the connected nutrient transport depend on the characteristics of the stream, the hydrograph of the flood wave and the actual conditions of the channel (Peterson and Benning, 2013).

The sources of the suspended sediments recorded at the catchment outlet also vary due to seasonally varying vegetation (Hearne et al., 1994). The development of aquatic macrophytes limits the discharge capacity of the channels. Keesstra et al. (2012) evaluated the effect of temporary variable vegetation cover within the natural and semi-natural headwater channels and the stream riparian zone on water and sediment transport. On the basis of numerical modelling, they concluded that vegetation affects resuspension especially during high-flow conditions in streams that are not sediment supply limited. Similarly, Huisman et al. (2013) showed that the previously suspended sediment is mobilized during the later parts of the year. In spring the recently eroded sediment is quickly flushed downstream. Shore et al. (2015) showed that in the case of well-trained channels there is greater potential for fast sediment transportation downstream. However, this is not necessarily the rule in sparsely maintained and over-vegetated channels, where the sediment retention capacity is not negligible.

The key questions that we will address in this paper are as follows.

- Can well-trained and well-regulated stream channels act as a temporal sediment trap and sediment source due to the resuspension of sediments deposited from previous erosion events?

- How does the flood wave transformation regime and the suspended solids remobilization regime change within one season as a consequence of various instream vegetation and baseflow conditions?
- How does the resuspended sediment concentration and the mass movement change in the event of repeated short flood waves?

To answer these questions, we initiated two sets of three small artificial floods into a typical drainage channel in the rural landscape of central Bohemia, Czech Republic. The experiments were performed recurrently in September and in March, when the channel vegetation, the baseflow, and the channel saturation differ most.

\section{Methods}

\subsection{Site description}

The experiments were performed in the stream which drains the Nučice rural experimental catchment, Czech Republic (Fig. 1). The Nučice catchment $\left(49^{\circ} 57^{\prime} 49.230^{\prime \prime} \mathrm{N}\right.$, $14^{\circ} 52^{\prime} 13.242^{\prime \prime} \mathrm{E}$ ) was established in 2011 with the main purpose to monitor and study the rainfall-runoff and soil erosion processes by water originating from intensive rainfall over cultivated fields (Zumr et al., 2015).

The catchment $\left(0.531 \mathrm{~km}^{2}\right)$ is located at elevations ranging from 382 to $417 \mathrm{~m}$ a.s.l. The inclination of the slopes varies between 1 and $12 \%$, the average slope being $3.9 \%$. The annual average precipitation is $630 \mathrm{~mm}$, and the annual evapotranspiration is $500 \mathrm{~mm}$. The mean air temperature is $6^{\circ} \mathrm{C}$, and the climate is considered as humid continental. The catchment is unique with its very uniform land use. More than $95 \%$ of the area is arable land, while the remaining parts are the watercourse, riparian trees and shrubs, and paved roads. There are no forests, grassland, or urbanized areas. The arable land is cultivated down to the stream banks, and conservation tillage is practised. The usual crops are winter wheat (Triticum aestivum L.), mustard (Sinapis alba L.), and rapeseed (Brassica napus). The soil types are classified as Cambisols and Luvisols. The topsoil has loamy texture with content of $13 \%$ clay, $42 \%$ silt, and $45 \%$ sand. The average annual topsoil saturated hydraulic conductivity is $4.8 \times 10^{-7} \mathrm{~m} \mathrm{~s}^{-1}$, and the mean organic carbon content is $1.9 \%$.

The Nučice catchment is drained by an artificially trained narrow stream, which has been piped in the uppermost part. The channel was modified into its current form in the $1950 \mathrm{~s}$, with the aim to decrease the groundwater level and to prevent inundation of the fields. The piped section is $530 \mathrm{~m}$ in length, and the open channel down to the outlet profile of the experimental catchment extends to $424 \mathrm{~m}$. The straight, deep channel is in direct contact with the surrounding fields. The riparian vegetation is only sparse.

The channel has a trapezoid profile which is $0.6 \mathrm{~m}$ in width at the stream bed, and the slope of the banks is $1: 2$. The stream bed and footslopes up to $0.3 \mathrm{~m}$ are stabilized with concrete tiles. There are two culverts on the stream. One is $56 \mathrm{~m}$ from the start of the open channel, and it is $0.8 \mathrm{~m}$ in inner 


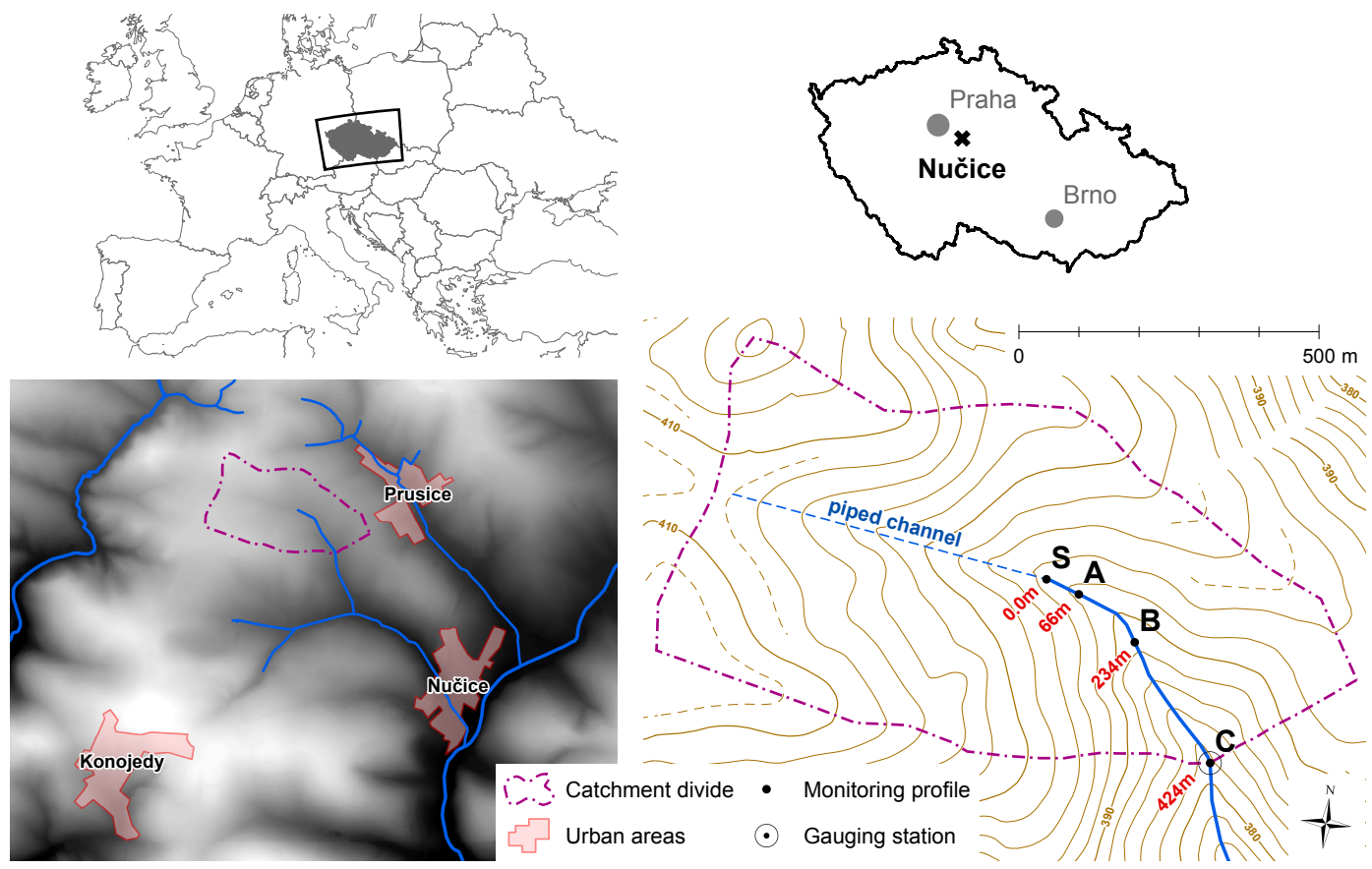

Figure 1. Map of the Nučice catchment with the measurement sites.

diameter and $10.2 \mathrm{~m}$ in length. The second culvert is $337 \mathrm{~m}$ from the start, and is $0.6 \mathrm{~m}$ in diameter and $7.8 \mathrm{~m}$ in length. The average depth of the channel is $1.5 \mathrm{~m}$. The current situation of the channel represents very well the situation in most small regulated drainage channels in the country: there has been very little maintenance during the last ca. 30 years. Locally, therefore, the stabilization is defective and the channel profile has been covered by extensive weed vegetation with a predominance of stinging nettles (Urtica dioica), orchard grass (Dactylis glomerata), pigweed (Chenopodium album), and hogweed (Heracleum sphondylium).

The typical flow conditions at the gauging station, as observed during the period of monitoring (2011-2016), are as low as $0.1-0.2 \mathrm{~L} \mathrm{~s}^{-1}$ during the summer months and around $4 \mathrm{~L} \mathrm{~s}^{-1}$ towards the end of winter. Summer storm-runoff events accompanied by an increase in the concentration of suspended solids in the runoff are characteristic events. The storms cause a short, steep wave with a concentration time of 50 to 240 min (Zumr et al., 2015).

\subsection{Experimental set-up}

The experiments were performed in the open section of the channel (Fig. 1). The total monitored length was $424 \mathrm{~m}$, which is the distance between the injection profile (profile $S$ ) and the basin closing profile (profile $\mathrm{C}$ ). The point where we injected water is considered as the start $(0 \mathrm{~m})$, and the basin outlet is considered as the end $(424 \mathrm{~m})$. The release profile was placed directly at the beginning of open channel section. Water was pumped into the stream over a period of $7 \mathrm{~min}$ simultaneously from a filled water reservoir and from the onboard supply of a fire truck, using four fire hoses. We used drinking water from a nearby reservoir. The total pumped water volume for each wave was approximately $17 \mathrm{~m}^{3}$. The very first wave (W1) was initiated with ca. $15 \mathrm{~m}^{3}$ of water, because the pump could not draft the remaining $2 \mathrm{~m}^{3}$ from the bottom of the water reservoir. The discharge fluctuated around $40 \mathrm{~L} \mathrm{~s}^{-1}$, and no significant peaks were produced during injection. The water was pumped first into a small stilling basin to prevent excessive disturbance to the streambed, and to be able to make precise measurements of the discharge produced by the pump. The discharge was measured with a mobile $\mathrm{H}$ flume, where the water level was recorded automatically with a pressure transducer.

We established three monitoring stations along the watercourse (Figs. 1 and 2) to monitor the discharge and the electrical conductivity, and to collect samples for measuring the concentration of the suspended solids. After taking the initial water sample for an evaluation of the baseflow water properties, we started the water sampling in each experimental profile immediately after the flood wave arrived. Samples approximately $1 \mathrm{~L}$ in volume were taken every minute during the rise, the peak, and shortly after the decrease of the discharge. After that, the sampling interval was reduced to 2 to $5 \mathrm{~min}$ intervals to obtain approximately 30 samples for each wave and observation profile. The samples were analysed in the laboratory. The concentration of suspended solids, phosphorus, and nitrogen were measured. Each station was equipped with a pre-programmed camera on a tri- 


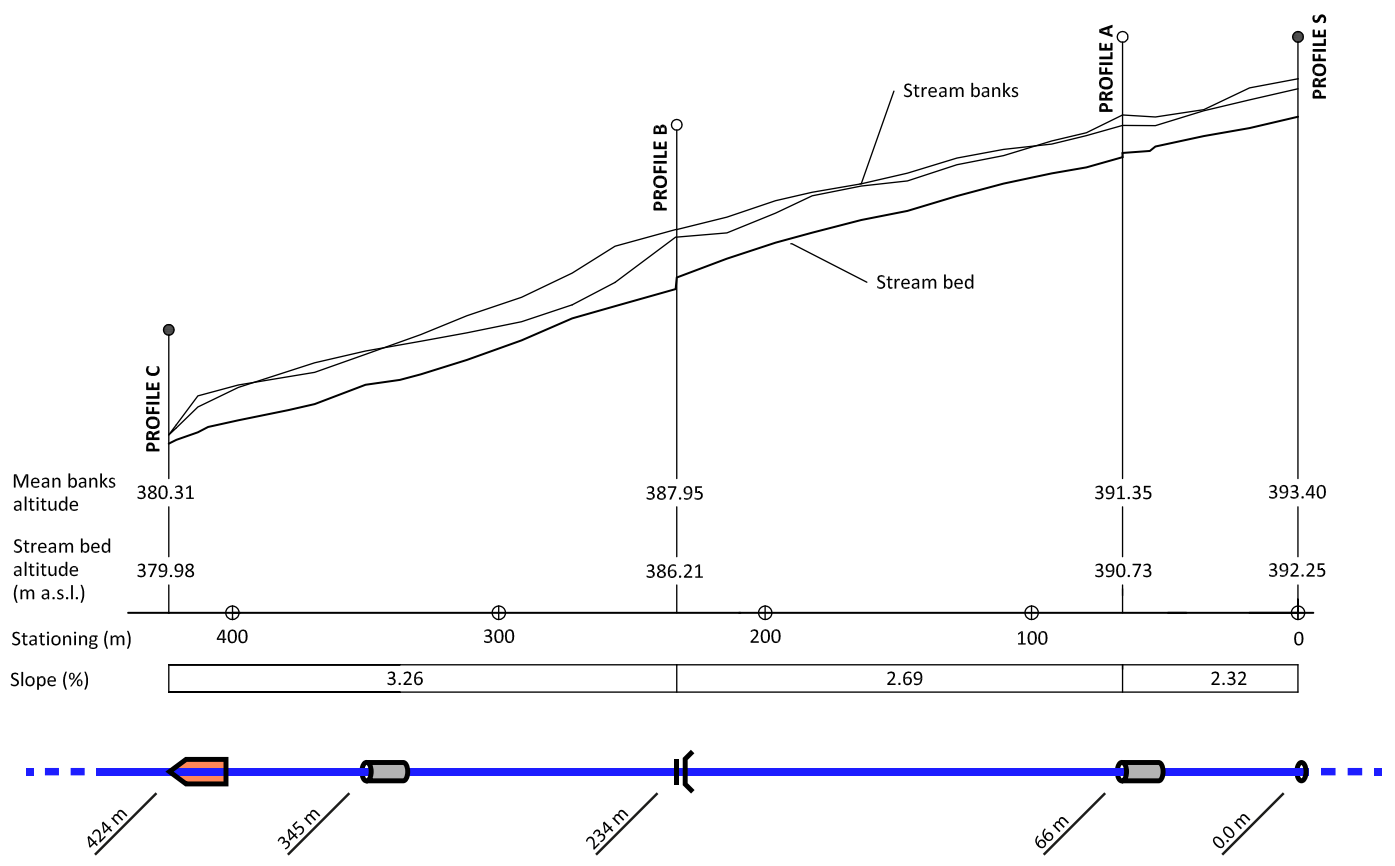

Figure 2. Stream longitudinal profile with monitoring sites and culverts on the Nučice experimental catchment.

pod to confirm the exact time of arrival of the wave and to document the progress of the wave and the sampling.

The first $66 \mathrm{~m}$ long section between pumping station $\mathrm{S}$ and profile A was meant to be used for wave dispersion and fluctuation stilling due to non-homogeneities in the pumping process. Station A was situated at the upper outlet of the culvert. The culvert ends with a free outflow, where the discharge was measured both volumetrically and hydrometrically. Monitoring profile $\mathrm{B}$, in a distance of $224 \mathrm{~m}$, was equipped with a rectangular weir, and the discharge was estimated on the basis of the measured depth of the water and the known rating curve. Profile $\mathrm{C}$ was located at the outlet of the experimental basin, positioned $424 \mathrm{~m}$ from the beginning of open channel section. The outlet is permanently equipped with an $\mathrm{H}$ flume with capacity of up to $400 \mathrm{~L} \mathrm{~s}^{-1}$. The $\mathrm{H}$ flume's inlet is $1.3 \mathrm{~m}$ wide and $0.68 \mathrm{~m}$ high, the straight approach length is $2 \mathrm{~m}$. The water depth was measured simultaneously with a pressure transducer and with an ultrasonic probe every $10 \mathrm{~s}$. The sediment concentration was measured in the lab on samples taken from the outlet and with a turbidity probe (ViSolid 700IQ, WTW, Germany) installed in a stilling basin below the $\mathrm{H}$ flume. The onsite data were logged automatically with a CR1000 data logger (Campbell Sci., UK). The electrical conductivity of the water in profiles B and C in September 2012 and in profiles A, B, and C in March 2013 was measured with HQ40D portable multimeters (Hach Lange, Germany).

The experiments were conducted in September 2012 and in March 2013. Within each of the campaigns we carried out three wave experiments (W1 to W3 in September, W4 to W6
Table 1. Initial conditions before the experiments.

\begin{tabular}{lll}
\hline Wave no. & W1, W2, W3 & W4, W5, W6 \\
\hline General conditions & Dry & Wet \\
Date & 4 September 2012 & 26 March 2013 \\
Baseflow $\left(\mathrm{L} \mathrm{s}^{-1}\right)$ & 0.4 & 1.5 \\
Soil moisture & Dry, below field & Nearly saturated \\
conditions & capacity & \\
Vegetation in channel & Extensive & Negligible \\
Air temperature $\left({ }^{\circ} \mathrm{C}\right)$ & 12 & -2 \\
Baseflow water & 7 & 2 \\
temperature $\left({ }^{\circ} \mathrm{C}\right)$ & & \\
\hline
\end{tabular}

in March). Subsequent waves were always initiated after the discharge in the outlet profile (station C) had dropped close to the initial baseflow. The second waves in the series (W2 and W5) were enriched with $\mathrm{NaCl}$ as a tracer to compare the water velocity and the water celerity during wave propagation. The tracer was dissolved in the water reservoir to obtain a concentration of approximately $6 \mathrm{~g} \mathrm{~L}^{-1}$. The first and third waves in each set contained no tracer.

The general conditions within the catchment and the stream prior to the experiments differed in September 2012 and in March 2013 (Table 1). In September, the stream baseflow was at its annual minimum, the soil water content was below its field capacity, and the instream vegetation was densely overgrown. In March 2013, the baseflow was at its annual maximum because of saturated soil from the snow melting, the instream vegetation was sparse, and the 

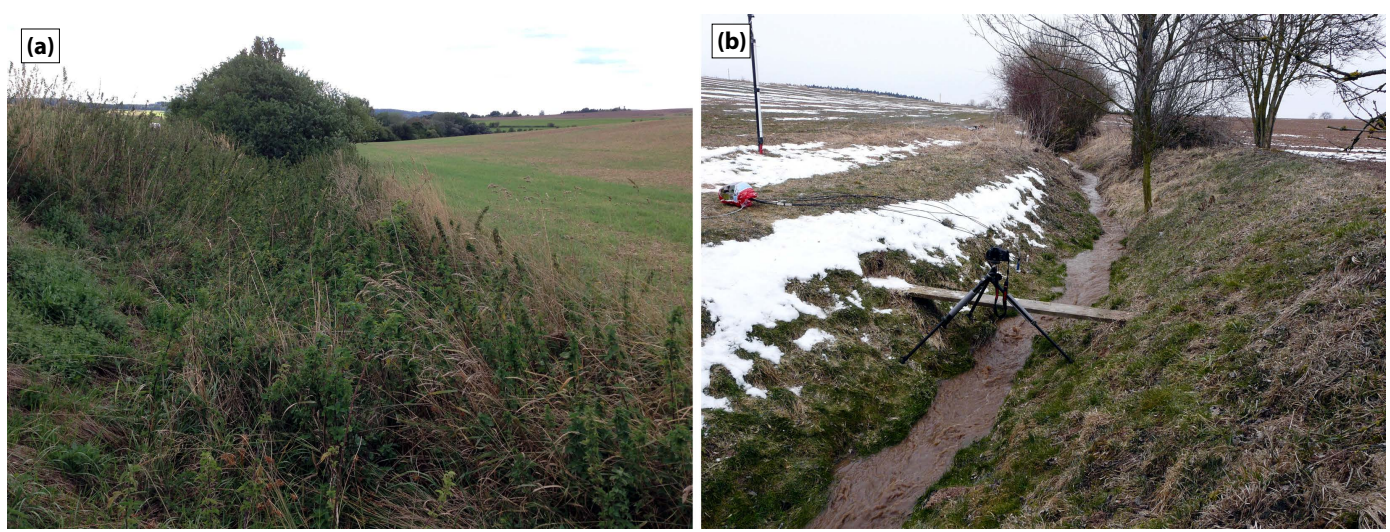

Figure 3. Stream vegetation conditions during the two experiments. Dense instream vegetation in September 2012 (a) and no erect vegetation in March 2013 (b).

remaining plants were flattened on the stream bed and banks (Fig. 3).

\subsection{Numerical modelling of the propagation of the waves}

For a quantitative evaluation of the impact of the vegetation on the transformation of the flood wave, we built a simple 1-D hydraulic model in HEC-RAS unsteady flow. The variable parameter between the September and March experiments was the stream roughness factor, which we attribute as a proxy of the actual character and density of the vegetation (Brookes, 1986). The approach is similar to the one of Nikora et al. (2008), who showed that the flow resistance is determined mainly by the general characteristics of the bulk instream vegetation, rather than by individual species. We assume that the vegetation resistance is mainly due to the stem blockage factor causing frictional energy losses, rather than by volume displacement effect, as the dense canopy occupies the cross section of the channel (Green, 2005).

The simulation of the hydraulic conditions in a channel system is based on a system of Saint Venant's equations. The evaluation of the energy gradient (friction slope) is based on Chézy's equation for velocity, where complex energy losses are represented by friction (Manning's formula). Unsteady flow is solved by the one-dimensional version of the finite difference method using the Preissman's implicit differential scheme.

The geometry of the channel was based on a set of 28 measured cross sections obtained by land surveying. To improve the precision of the simulations and to overcome numerical stability problems, intermediate profiles were added to the model by geometrical interpolation between the original cross sections. The average distance between cross sections in the final geometry set was $0.5 \mathrm{~m}$. Moreover, each cross section was extended by a narrow Preismann bottom slot to deal with numerical stability issues in cases of very low discharges (propagation of the wave in an originally dry chan- nel). The model was loaded on the upper end with the measured flow. The rating curve based on the Chezy equation for uniform flow was used as a downstream boundary condition.

The water exfiltration into the channel banks was simulated with the Richards equation; van Genuchten's model for soil water retention curve was used. The hydraulic characteristics and the saturated hydraulic conductivity of the stream banks were assumed to be the same as the measured subsoil matrix characteristics on the surrounding fields (residual water content $\theta_{\mathrm{r}}=0.095 \mathrm{~cm}^{3} \mathrm{~cm}^{-3}$, saturated water content $\theta_{\mathrm{S}}=0.44 \mathrm{~cm}^{3} \mathrm{~cm}^{-3}, \alpha=0.019 \mathrm{~cm}^{-1}, n=1.31, K_{\mathrm{S}}=$ $2.3 \times 10^{-7} \mathrm{~m} \mathrm{~s}^{-1}$ ). The modelling procedure was identical to the methodology described in Zumr and Císlerová (2010).

\section{Results}

The hydrographs and sedigraphs of all six waves are shown in Figs. 4-6. The shape characteristics of the waves and the transformation are summarized in Table 2 . The water and sediment balance are presented in Table 3 .

\subsection{Water flow regime}

The hydrographs of the subsequent experiments differed on all the monitoring profiles. The velocity of the waves and the maximum flow rates increased between the successive waves (Fig. 4). All the waves approached the A profile less than $5 \mathrm{~min}$ after the start of the experiments, and the subsequent waves reached the profile slightly earlier. The time difference between the approaches of waves W1 and W3 is $41 \mathrm{~s}$. Waves W1 and W2 reached a similar peak discharge of approximately $30 \mathrm{~L} \mathrm{~s}^{-1}$, and wave $\mathrm{W} 3$ reached a peak discharge of $36.3 \mathrm{~L} \mathrm{~s}^{-1}$. The difference was mainly caused by the slightly fluctuating rate of water pumping and by transient filling of the depression storages on the channel bed during the first wave experiment. Water exfiltration into the hyporheic zone contributed only a little over such a short dis- 

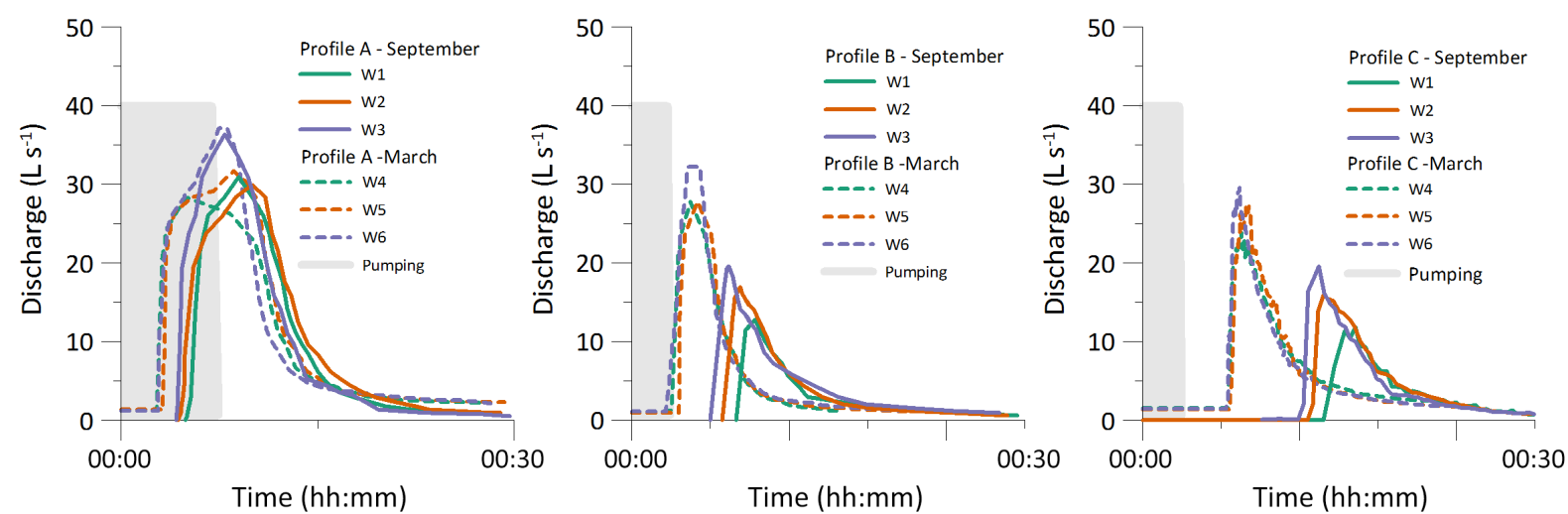

Figure 4. Hydrographs of flood propagation along the monitored stream in the Nučice catchment. The different dynamics in September (W1-W3) and March (W4-W6) are caused by the current state of the stream and the vegetation conditions.
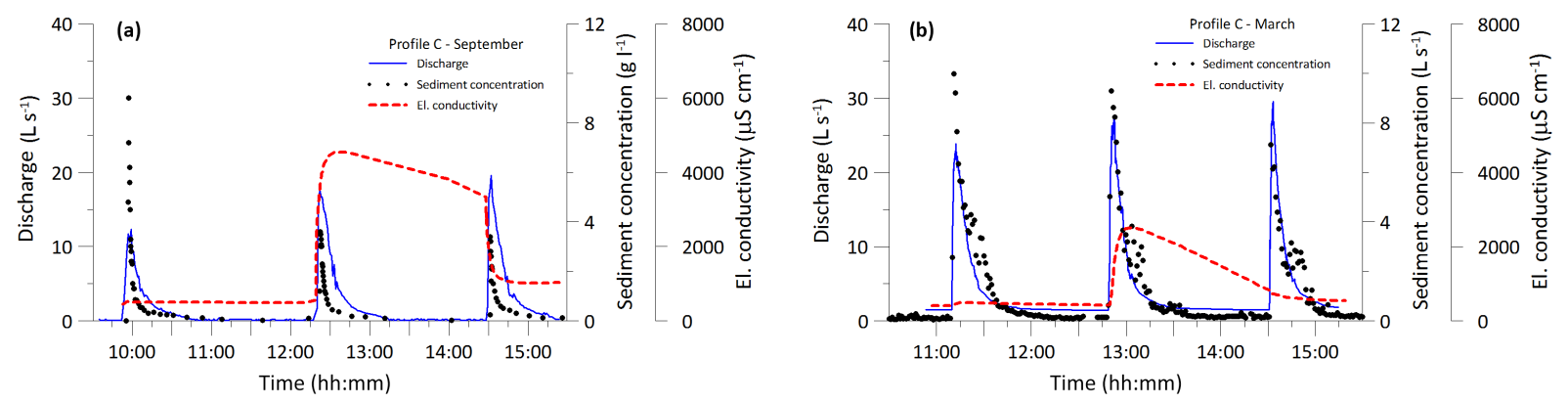

Figure 5. Measured outflow rates and the concentration of suspended solids in the Nučice catchment outlet during experiments conducted in September 2012 (a) and in March 2013 (b). The sediment mobility in September was limited by the lower peak discharge rates due to high vegetation density and dry initial conditions.

tance and period of time, as was also observed by ExnerKittridge et al. (2016).

The time lags in the B profile already differed. Wave $\mathrm{W} 1$ arrived after almost $20 \mathrm{~min}$. Waves W2 and W3 were faster, and appeared $15 \mathrm{~min}$ after pumping began. The peak discharge also increased, with subsequent waves starting at $12.8 \mathrm{~L} \mathrm{~s}^{-1}$ for $\mathrm{W} 1$ and reaching $19.6 \mathrm{~L} \mathrm{~s}^{-1}$ for $\mathrm{W} 3$. The difference between the arrival times of $\mathrm{W} 1$ and $\mathrm{W} 3$ in the $\mathrm{C}$ profile was also $5 \mathrm{~min}$, and the maximum flow rate increased from $12.3 \mathrm{~L} \mathrm{~s}^{-1}$ (W1) to $19.6 \mathrm{~L} \mathrm{~s}^{-1}$ (W3). The volume of water that reached the closing profile was $9.8 \mathrm{~m}^{3}$ for $\mathrm{W} 1$, $13.7 \mathrm{~m}^{3}$ for $\mathrm{W} 2$ and $14.8 \mathrm{~m}^{3}$ for $\mathrm{W} 3$. Within $\mathrm{W} 1$, only $69 \%$ of the pumped water was recovered in the $\mathrm{C}$ profile. For $\mathrm{W} 2$ and $\mathrm{W} 3$, the recovery rate was $90 \%$.

The wave celerity along the stream was calculated according to the wave arrival time, which we defined as the time of the first rise of the hydrograph (Table 2). The average wave celerity for $\mathrm{W} 1$ was $0.20 \mathrm{~m} \mathrm{~s}^{-1}$, for $\mathrm{W} 2$ it was $0.23 \mathrm{~m} \mathrm{~s}^{-1}$, and for $\mathrm{W} 3$ the celerity was $0.24 \mathrm{~m} \mathrm{~s}^{-1}$. The water flow velocity was calculated on the basis of the time of arrival of the tracer. The tracer was always detected later than the rise in the hydrograph (Fig. 5). The mean water flow velocity was $0.15 \mathrm{~m} \mathrm{~s}^{-1}$.
The hydrographs of waves W3-W6 are very similar to each other, and the time lags differ by less than $1 \mathrm{~min}$. The waves approached profile A after $3 \mathrm{~min}$, profile $\mathrm{B}$ after $9 \mathrm{~min}$, and profile $\mathrm{C}$ after $16 \mathrm{~min}$. The peak discharge values observed in the individual profiles were also similar, but the last wave, W6, reached slightly higher values. The average peak discharge of W4 to W6 in profile A was $32.5 \mathrm{~L} \mathrm{~s}^{-1}$, in profile $\mathrm{B}$ the peak discharge was $29.3 \mathrm{~L} \mathrm{~s}^{-1}$, and in profile $\mathrm{C}$ the peak discharge was $26.5 \mathrm{~L} \mathrm{~s}^{-1}$. The initial pumped water volume was $85 \%$ recovered in the $\mathrm{C}$ profile in all the March experiments, which is similar to the results for waves W2 and W3 (in the September experiment). The waves propagated with average celerity of $0.44 \mathrm{~m} \mathrm{~s}^{-1}$, which is twice the velocity of the September waves.

For each flood wave, the simulated flow hydrograph at the downstream end was compared with the measured discharge data (Fig. 6). The accuracy of the fit was evaluated by comparing two characteristic parameters - the time and the discharge at the wave peak. Manning's hydraulic roughness was used as the calibration parameter, separately for the September scenario and for the March scenario. 
Table 2. Hydrograph characteristics. n/a: data not available.

\begin{tabular}{|c|c|c|c|c|c|c|c|c|c|}
\hline \multirow[t]{2}{*}{ Wave no. } & \multirow[t]{2}{*}{ Profile } & \multirow{2}{*}{$\begin{array}{l}\text { Time of first } \\
\text { arrival (mm:ss) }\end{array}$} & \multicolumn{2}{|c|}{ Peak } & \multicolumn{2}{|c|}{ Duration of limb } & \multirow[t]{2}{*}{ Volume $\left(\mathrm{m}^{3}\right)$} & \multirow{2}{*}{$\frac{\text { Wave celerity }}{\left(\mathrm{m} \mathrm{s}^{-1}\right)}$} & \multirow{2}{*}{$\frac{\text { Wave velocity }}{\left(\mathrm{m} \mathrm{s}^{-1}\right)}$} \\
\hline & & & discharge $\left(\mathrm{Ls}^{-1}\right)$ & time (mm:ss) & rising & falling & & & \\
\hline \multirow[t]{3}{*}{ W1 } & A & $04: 53$ & 30.9 & 09:00 & 04:07 & $26: 10$ & 14.2 & 0.23 & $\mathrm{n} / \mathrm{a}$ \\
\hline & $\mathrm{B}$ & $19: 53$ & 12.8 & $23: 25$ & $03: 32$ & 40:00 & 9.9 & 0.19 & $\mathrm{n} / \mathrm{a}$ \\
\hline & $\mathrm{C}$ & $34: 35$ & 12.3 & $40: 35$ & 06:00 & $40: 00$ & 9.8 & 0.22 & $\mathrm{n} / \mathrm{a}$ \\
\hline \multirow[t]{3}{*}{ W2 } & A & $04: 22$ & 29.9 & $10: 00$ & $05: 38$ & $31: 50$ & 16.0 & 0.25 & $\mathrm{n} / \mathrm{a}$ \\
\hline & $\mathrm{B}$ & $17: 13$ & 16.9 & $20: 40$ & $03: 27$ & $45: 00$ & 12.9 & 0.22 & 0.13 \\
\hline & $\mathrm{C}$ & $31: 29$ & 17.7 & $34: 29$ & 03:00 & $47: 00$ & 13.7 & 0.22 & 0.15 \\
\hline \multirow[t]{3}{*}{ W3 } & A & $04: 12$ & 36.3 & $07: 55$ & $06: 43$ & $28: 45$ & 16.4 & 0.26 & $\mathrm{n} / \mathrm{a}$ \\
\hline & $\mathrm{B}$ & $15: 00$ & 19.6 & $08: 32$ & $03: 32$ & $44: 28$ & 15.8 & 0.26 & $\mathrm{n} / \mathrm{a}$ \\
\hline & $\mathrm{C}$ & $29: 40$ & 19.6 & $33: 40$ & 04:00 & $44: 00$ & 14.8 & 0.22 & $\mathrm{n} / \mathrm{a}$ \\
\hline \multirow[t]{3}{*}{ W4 } & $\mathrm{A}$ & 3:08 & 28.4 & $4: 55$ & $1: 47$ & $27: 30$ & 14.6 & 0.35 & $\mathrm{n} / \mathrm{a}$ \\
\hline & $\mathrm{B}$ & $8: 36$ & 27.9 & $11: 14$ & $2: 38$ & $35: 30$ & 14.5 & 0.45 & $\mathrm{n} / \mathrm{a}$ \\
\hline & $\mathrm{C}$ & $16: 28$ & 22.8 & $19: 23$ & $2: 55$ & $41: 00$ & 13.3 & 0.43 & $\mathrm{n} / \mathrm{a}$ \\
\hline \multirow[t]{3}{*}{ W5 } & A & $3: 15$ & 31.8 & $5: 24$ & 2:09 & $27: 00$ & 16.3 & 0.34 & 0.09 \\
\hline & B & $9: 14$ & 27.8 & $12: 35$ & $3: 21$ & $33: 00$ & 14.1 & 0.42 & 0.19 \\
\hline & $\mathrm{C}$ & $16: 45$ & 27.2 & $20: 20$ & $3: 35$ & $44: 00$ & 14.5 & 0.42 & 0.14 \\
\hline \multirow[t]{3}{*}{ W6 } & A & $2: 51$ & 37.2 & 8:06 & $5: 15$ & $28: 30$ & 16.3 & 0.39 & $\mathrm{n} / \mathrm{a}$ \\
\hline & B & $8: 54$ & 32.2 & $13: 00$ & $4: 06$ & $32: 30$ & 16.2 & 0.44 & $\mathrm{n} / \mathrm{a}$ \\
\hline & $\mathrm{C}$ & $15: 58$ & 29.6 & $18: 33$ & $2: 35$ & $44: 00$ & 14.1 & 0.44 & $\mathrm{n} / \mathrm{a}$ \\
\hline
\end{tabular}
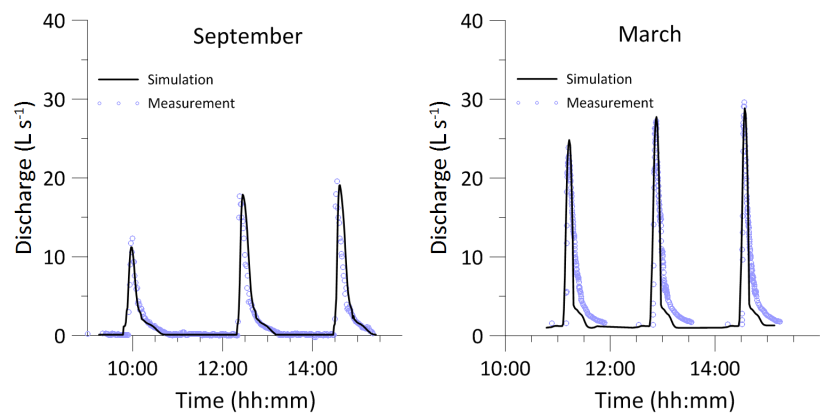

Figure 6. Comparison of the flood wave characteristics measured at the gauging profile and simulated by HEC-RAS.

Table 3. Water and sediment budget as measured at the gauging stations (profile $\mathrm{C}$ ).

\begin{tabular}{lrrr}
\hline Wave no. & $\begin{array}{r}\text { Inflow } \\
\text { volume } \\
\left(\mathrm{m}^{3}\right)\end{array}$ & $\begin{array}{r}\text { Outflow } \\
\text { volume } \\
\left(\mathrm{m}^{3}\right)\end{array}$ & $\begin{array}{r}\text { Cumulative sediment } \\
\text { mass at the } \\
\text { outlet }(\mathrm{kg})\end{array}$ \\
\hline W1 & 14.2 & $9.8(69 \%)$ & 18.2 \\
W2 & 16.0 & $13.7(86 \%)$ & 13.8 \\
W3 & 16.4 & $14.8(90 \%)$ & 9.6 \\
W4 & 15.7 & $13.3(85 \%)$ & 48.5 \\
W5 & 17.2 & $14.5(84 \%)$ & 45.3 \\
W6 & 16.4 & $14.1(86 \%)$ & 30.7 \\
\hline
\end{tabular}

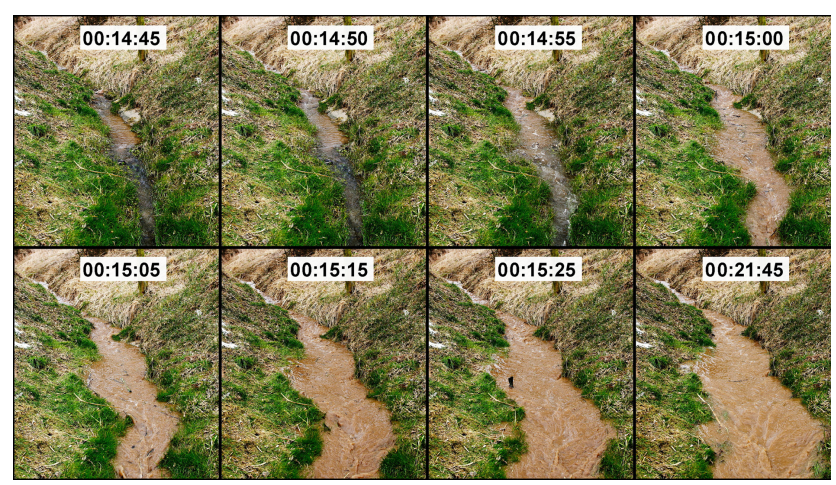

Figure 7. The approach of the W4 wave front at stationing of $400 \mathrm{~m}$. The times (hh:mm:ss) stand for the duration from the start of the experiment.

\subsection{Sediment regime}

The total amount of sediment released during the September experimental campaign was $41.6 \mathrm{~kg}$, and during the March experimental campaign the amount was $124.5 \mathrm{~kg}$. Assuming regular initial distribution and uniform release of the sediment, this represents $0.10 \mathrm{~kg} \mathrm{~m}^{-1}$ of the channel for the September campaign and $0.29 \mathrm{~kg} \mathrm{~m}^{-1}$ of the channel for the March campaign.

The maximum suspended solids concentration in profile $\mathrm{A}$, with a value of $9 \mathrm{~g} \mathrm{~L}^{-1}$, was observed at the moment when W1 and W4 were approaching (Fig. 7). The minimum peak concentration of $1.7 \mathrm{~g} \mathrm{~L}^{-1}$ was reached for wave W3. In 
profile $\mathrm{C}$, the peak sediment concentration reached $7.5 \mathrm{~g} \mathrm{~L}^{-1}$ and dropped to $3.9 \mathrm{~g} \mathrm{~L}^{-1}$ for waves $\mathrm{W} 2$ and $3.7 \mathrm{~g} \mathrm{~L}^{-1}$ for wave W3. The total sediment mass that passed the catchment outlet was $18.2 \mathrm{~kg}$ during the first wave, $13.8 \mathrm{~kg}$ during W2, and $9.6 \mathrm{~kg}$ during $\mathrm{W} 3$.

The amount of carried sediment measured at site $\mathrm{C}$ decreased from 48.5 to $30.7 \mathrm{~kg}$ between waves W4 and W6. The peak concentration of suspended solids in profile $\mathrm{C}$ reached close to $8 \mathrm{~g} \mathrm{~L}^{-1}$ for W5 and $5 \mathrm{~g} \mathrm{~L}^{-1}$ for W6.

\section{Discussion}

\subsection{A comparison with the results from a natural catchment}

The set-up of our experiment was based on a study made by Eder et al. (2014), who carried out two flushing experiments in a natural stream in the HOAL experimental catchment in Austria (Blöschl et al., 2016). The catchment is similar in size, climate, soils, and management to the Nučice catchment. The HOAL stream meanders through a forested belt. The monitored length is $590 \mathrm{~m}$, with an average slope of $2.4 \%$. The stream cross section is irregular, and the channel width varies from 0.6 to $1.0 \mathrm{~m}$. The longitudinal slope is relatively homogeneous over the whole monitored length, with the exception of the initial $90 \mathrm{~m}$, which are significantly steeper. Our experimental section had a convex course, with the slope gradually increasing from $2.3 \%$ in the first section of ca. $70 \mathrm{~m}$ to $3.3 \%$ in the last section ca. $200 \mathrm{~m}$ in length (nearly half of the length of the total monitored course).

The HOAL experiments were carried out in August 2011 on 2 days separated from each other by a gap of approximately 1 week. The volume of pumped water was $17 \mathrm{~m}^{3}$, and the wave propagation was monitored on three observation sites. The two recurrent waves had a very similar character. The average celerity was $0.22 \mathrm{~m} \mathrm{~s}^{-1}$, which corresponds very well with the celerity measured in our experiment in summer conditions (waves W1-W3), and reached about $50 \%$ celerity in comparison to our experiment in March (waves W4-W6). The amount of water recovered in the closing profile was 79 and $75 \%$ of the pumped volume, which is comparable with Nučice experiments W1 to W3. However, the wave transformation in HOAL was extreme, and the peak discharges were reduced from 57 to $8.7 \mathrm{~L} \mathrm{~s}^{-1}$ and $7.9 \mathrm{~L} \mathrm{~s}^{-1}$ at the outlet profile. This is due to lowering of the longitudinal profile, and probably also due to higher surface roughness of the natural stream channel. In the HOAL experiments, only 7.0 and $7.7 \mathrm{~kg}$ of suspended solids were recorded, which is only about $50 \%$ of the amounts of sediment for the Nučice catchment in September conditions, and $15 \%$ of the amounts of sediment for the Nučice catchment in March. Both the HOAL experiment and the Nučice experiment resulted in major stream bed sediment mobilization during the rising limb of the hydrograph. A similar sediment regime in chan- nels has also been observed during large flood events on other streams (Guan et al., 2015). A comparison of the measured hydrographs and the physical and geometrical characteristics of the stream channels shows that, for the HOAL experiment, there is an extremely high flood wave transformation, with relatively low retention. This is partly due to the decreasing longitudinal slope of the river bed, and partly due to the higher surface roughness of the natural stream channel. It shows that the transport capacity of the generated waves was exceeded and the amount of transported sediment decreases along the monitored course. In the Nučice experiment, the flood wave transformation was considerably lower. However, we observed relatively significant water retention in the first experiment in September (see the section in the Results referring to mathematical hydraulic modelling). We conclude that the transport capacity of the flood wave was exceeded during the HOAL experiment, and detached sediment from upper, steeper parts of the experimental course was redeposited downstream, as in most of the natural streams monitored by Naden et al. (2016). By contrast, during our experiment in Nučice, the transport capacity of the flood waves was not reached, either in September or March. The sediment concentrations and also the fluxes therefore increased continuously throughout the section.

\subsection{Stream potential for sediment trapping}

We have to keep in mind that the artificial flood waves used in this experiment were relatively small in volume and of short duration. Based on the monitoring of the natural runoff events, we estimate that the minimum time needed for complete bedload sediment removal with comparable discharge is in the range of $10-24 \mathrm{~h}$ (Zumr et al., 2015). Although the amount of sediment transported by the waves decreased within each set of experiments, there was still enough sediment left in the channel that could be released if there were to be a larger wave. The clockwise hysteresis of the sediment concentration-discharge relation suggests that the sediment originates from nearby. Similar results were observed, for example, by Molder et al. (2015) and Seeger et al. (2004). The amount of resuspended sediment was significantly lower in summer conditions. We relate this to the particular conditions in the channel with dense erect vegetation and dry conditions, which led to storage of a considerable proportion of the water.

Significant changes in surface roughness, which also affect this process, may be documented by mathematical modelling of the movement of the wave through the experimental section using a 1-D hydraulic model.

These processes, though with reverse trends exhibiting a decrease in the amount of resuspended sediment over sections downstream, due to very different stream channel characteristics, have also been confirmed by the similar HOAL experiment, performed by Eder et al. (2014). The results clearly show the potential of even well-trained channels with- 
out visible signs of sediment accumulation to release sediment during flood events.

The experiments showed that a well-trained stream can act both as a trap and as a sediment source. However, the hydraulic characteristics of the flood wave and the physical and geometrical characteristics of the channel will be crucial for indicating whether deposition or remobilization will occur in a given section and during a given event.

\subsection{Temporal variability of sediment resuspension}

All the sedigraphs show similar behaviour (Fig. 5). The sediment concentration increases rapidly immediately after the arrival of the wave. The highest sediment concentration is always directly measured at the wave front, and does not necessarily correspond to the peak discharge. After culmination of the wave, the concentration of the sediment also decreases. The highest sediment concentration peak was observed when waves W1 and W4 were approaching, i.e. in the initial experiment of each campaign. We relate this to the fine-textured sediment that had been deposited in the stream during previous events. Our initial assumption was that most of the solid particles move only a short distance, because of low water velocity and short wave duration. Only the finest particles would be mobile enough to travel longer distances. However, our experiment showed that while the discharges decreased along experimental sections A to $\mathrm{C}$, the sediment concentration increased (see Tables 2, 3 and Fig. 4). This suggests that the transport capacity of the stream had not been reached, even for lower discharges at the outlet point, and at least fine-textured soil particles were resuspended and transported over the whole observed section of the stream channel. To test this assumption, we estimated the maximum clear water transport capacity during the observed flow according to the simple transport capacity equation proposed by Govers (1990). The transport capacity of the peak flow was $990 \mathrm{~g} \mathrm{~L}^{-1}$, which greatly exceeds the measured values. The sediment concentration behaviour during waves W2 to W6 was similar (Fig. 5).

The remobilized sediment mass was two to three times higher in March than in September. We relate this to higher water velocity, as a result of which heavier particles contribute to the recorded amount, due to the higher transport capacity. It is not technically possible to measure the total initial mass of the sediment in the stream, and we can only make an estimate on the basis of previous runoff events that the conditions in September and March were similar, and were close to a quasi-steady state for the stream. In both cases, the last antecedent erosion event had taken place more than 2 months before the experiment, followed by at least one runoff event when no soil erosion was recorded and the discharge was above $5 \mathrm{Ls}^{-1}$.

The experiments confirmed our assumption that vegetation development is a crucial parameter that affects flood wave retention and propagation, as well as the sediment dynamics.
Contrasting vegetation conditions are documented by Fig. 3 fully erect well-developed dense vegetation in the September set of experiments (W1-W3) vs. no erect vegetation in the March set of experiments (W4-W6).

The general behaviour of the sediment transport during both sets of experiments (September conditions vs. March conditions) is the same, since the bedload sediment is available throughout the year. In both cases, it decreases event by event, but the sediment load increases along the sections. The general difference between the resuspension in fullydeveloped vegetation (September) vs. the March conditions is 2.7 times higher for the first event and 3.2 times higher for the second and third events, as regards total transported sediment. As regards sediment concentrations, the peak values were the same for the first events and ca. $50 \%$ for the second and third events. Well-developed vegetation therefore significantly increased the trapping capacity of the stream channel (Keesstra et al., 2012).

The flood waves propagate differently in September and in March. While in September the successive waves speed up, in March the wave velocities are very similar for all experiments. When we compare the speed of flood propagation in a vegetated channel and in an empty channel, the March waves propagate twice as fast, and reach a $30 \%$ higher peak discharge. The reason is twofold: (i) there is higher vegetation resistance in September, and (ii) there is higher baseflow and therefore a greater difference between the water velocity and the wave celerity in March. The volume of water recovered on site $\mathrm{C}$ is slightly larger during the March experiments. It should be noted that in reality the general summer and winter regime may vary because of variable rainfall patterns and catchment conditions (Buendia et al., 2016; Walling and Amos, 1999).

There is a significant water loss in the case of wave W1, which was released into an almost empty channel with dry stream banks (Table 1). Because of water exfiltration, interception on the vegetation, and filling of the streambed depressions along the $424 \mathrm{~m}$ long channel, the water loss reached $31 \%$. During all other experiments, including W4, the water loss was only $10-15 \%$.

A comparison of the simulated hydrographs and the measured hydrographs is presented in Fig. 6. It can be stated that the numerical simulations mimic the monitored hydrographs, and the effect of the vegetation seems to be a correct assumption. In the simulation of the September experiments, very high Manning roughness values $(n=0.20)$ were reached, while in March the optimized Manning $n$ was equal to 0.12 . The values fit well into the common ranges for sparsely vegetated and densely vegetated streams published, for example, by Luhar et al. (2008) and by Vereecken et al. (2006). 


\section{Conclusion}

Our paper has presented the methodology for an artificial flood experiment conducted on an experimental agricultural catchment, and the results of the experiment. Three successive flood waves, each with an approximate volume of $17 \mathrm{~m}^{3}$, were released into the upper part of the drainage channel. The aim was to monitor the transformation of the flood wave and the sediment transport within the channel.

On the basis of our results, we concluded that even welltrained and straight channels trap sediment, which can be mobilized by subsequent small floods.

The resuspension regime depends on the current conditions of the stream and the instream vegetation, and therefore changes significantly in the course of a year. The sediment moves quickly in winter and early spring, but in the later part of the year the channel serves as a sediment trap and the resuspension is slower, if dense vegetation is present.

The resuspension regime and the sediment loads within the succeeding small flood waves do not change considerably. The artificial waves that we initiated do not have sufficient magnitude to flush the bedload sediment out from the entire channel.

Data availability. All data is available upon request.

Author contributions. DZ managed the experiments, analysed data, and prepared the paper with contributions from all the other coauthors. TD and JD co-organized the experiments. PV did the HECRAS simulation. PR was responsible for all the laboratory analyses. PS and AE participated on the experiments and the data evaluation.

Competing interests. The authors declare that they have no conflict of interest.

Acknowledgements. We thank our colleagues Josef Krása, Václav David, Petr Koudelka, Luděk Strouhal, Vladimír Říha and Dan Fiala for their great help during the experiments. This research was prepared within the framework of Czech Science Foundation postdoctoral project GP13-20388P, Ministry of Agriculture projects NAZV QJ1230056 and QJ1530181, and ÖAD WTZ Mobility project no. CZ18/2016 - 7AMB16AT002.

Edited by: Patricia Saco

Reviewed by: two anonymous referees

\section{References}

Báčová, M. and Krása, J.: Application of Historical and Recent Aerial Imagery in Monitoring Water Erosion Occurrences in Czech Highlands, Soil Water Res., 11, 267-276, https://doi.org/10.17221/178/2015-SWR, 2016.
Blöschl, G., Blaschke, A. P., Broer, M., Bucher, C., Carr, G., Chen, X., Eder, A., Exner-Kittridge, M., Farnleitner, A., Flores-Orozco, A., Haas, P., Hogan, P., Kazemi Amiri, A., Oismüller, M., Parajka, J., Silasari, R., Stadler, P., Strauss, P., Vreugdenhil, M., Wagner, W., and Zessner, M.: The Hydrological Open Air Laboratory (HOAL) in Petzenkirchen: a hypothesis-driven observatory, Hydrol. Earth Syst. Sci., 20, 227-255, https://doi.org/10.5194/hess20-227-2016, 2016.

Boardman, J.: Soil erosion and flooding on the eastern South Downs, southern England, 1976-2001, Trans. Inst. Br. Geogr., 28, 176-196, https://doi.org/10.1111/1475-5661.00086, 2003.

Brookes, A.: Response of aquatic vegetation to sedimentation downstream from river channelisation works in England and Wales, Biol. Conserv., 38, 351-367, https://doi.org/10.1016/0006-3207(86)90060-1, 1986.

Buendia, C., Vericat, D., Batalla, R. J., and Gibbins, C. N.: Temporal Dynamics of Sediment Transport and Transient In-channel Storage in a Highly Erodible Catchment, Land Degrad. Dev., 27, 1045-1063, https://doi.org/10.1002/ldr.2348, 2016.

Drummond, J. D., Davies-Colley, R. J., Stott, R., Sukias, J. P., Nagels, J. W., Sharp, A., and Packman, A. I.: Retention and remobilization dynamics of fine particles and microorganisms in pastoral streams, Water Res., 66, 459-472, https://doi.org/10.1016/j.watres.2014.08.025, 2014.

Eder, A., Exner-Kittridge, M., Strauss, P., and Blöschl, G.: Resuspension of bed sediment in a small stream - results from two flushing experiments, Hydrol. Earth Syst. Sci., 18, 1043-1052, https://doi.org/10.5194/hess-18-1043-2014, 2014.

Exner-Kittridge, M., Strauss, P., Blöschl, G., Eder, A., Saracevic, E., and Zessner, M.: The seasonal dynamics of the stream sources and input flow paths of water and nitrogen of an Austrian headwater agricultural catchment, Sci. Total Environ., 542, 935-945, https://doi.org/10.1016/j.scitotenv.2015.10.151, 2016.

Govers, G.: Empirical relationships for transport capacity of overland flow, IAHS Publ., 189, 45-63, 1990.

Green, J. C.: Modelling flow resistance in vegetated streams: review and development of new theory, Hydrol. Process., 19, 12451259, https://doi.org/10.1002/hyp.5564, 2005.

Guan, M., Wright, N. G., and Andrew Sleigh, P.: Multiple effects of sediment transport and geomorphic processes within flood events: Modelling and understanding, Int. J. Sediment Res., 30, 371-381, https://doi.org/10.1016/j.ijsrc.2014.12.001, 2015.

Hearne, J., Johnson, I., and Armitage, P.: Determination of ecologically acceptable flows in rivers with seasonal changes in the density of macrophyte, Regul. Rivers Res. Manag., 9, 177-184, https://doi.org/10.1002/rrr.3450090304, 1994.

Hession, W., Pizzuto, J., Johnson, T., and Horwitz, R.: Influence of bank vegetation on channel morphology in rural and urban watersheds, Geology, 31, 147-150, https://doi.org/10.1130/00917613(2003)0312.0.CO;2, 2003.

Huisman, N. L. H., Karthikeyan, K. G., Lamba, J., Thompson, A. M., and Peaslee, G.: Quantification of seasonal sediment and phosphorus transport dynamics in an agricultural watershed using radiometric fingerprinting techniques, J. Soils Sediments, 13, 1724-1734, https://doi.org/10.1007/s11368-013-0769-0, 2013.

Keesstra, S. D., Kondrlova, E., Czajka, A., Seeger, M., and Maroulis, J.: Assessing riparian zone impacts on water and sediment movement: a new approach, Neth. J. Geosci., 91, 245-255, https://doi.org/10.1017/S0016774600001633, 2012. 
Lal, R.: Soil Erosion Impact on Agronomic Productivity and Environment Quality, Crit. Rev. Plant Sci., 17, 319-464, https://doi.org/10.1080/07352689891304249, 1998.

Lal, R., Follett, R. F., Stewart, B. A., and Kimble, J. M.: Soil carbon sequestration to mitigate climate change and advanced food security, Soil Sci., 172, 943-956, https://doi.org/10.1097/ss.0b013e31815cc498, 2007.

Luhar, M., Rominger, J., and Nepf, H.: Interaction between flow, transport and vegetation spatial structure, Environ. Fluid Mech., 8, 423-439, https://doi.org/10.1007/s10652-008-9080-9, 2008.

Minella, J. P. G., Walling, D. E., and Merten, G. H.: Combining sediment source tracing techniques with traditional monitoring to assess the impact of improved land management on catchment sediment yields, J. Hydrol., 348, 546-563, https://doi.org/10.1016/j.jhydrol.2007.10.026, 2008.

Molder, B., Cockburn, J., Berg, A., Lindsay, J., and Woodrow, K.: Sediment-assisted nutrient transfer from a small, no-till, tile drained watershed in Southwestern Ontario, Canada, Agr. Water Manage., 152, 31-40, https://doi.org/10.1016/j.agwat.2014.12.010, 2015.

Musolff, A., Schmidt, C., Selle, B., and Fleckenstein, J. H.: Catchment controls on solute export, Adv. Water Resour., 86, 133-146, https://doi.org/10.1016/j.advwatres.2015.09.026, 2015.

Naden, P. S., Murphy, J. F., Old, G. H., Newman, J., Scarlett, P., Harman, M., Duerdoth, C. P., Hawczak, A., Pretty, J. L., Arnold, A., Laizé, C., Hornby, D. D., Collins, A. L., Sear, D. A., and Jones, J. I.: Understanding the controls on deposited fine sediment in the streams of agricultural catchments, Sci. Total Environ., 547, 366-381, https://doi.org/10.1016/j.scitotenv.2015.12.079, 2016.

Neal, C. W. M. and Anders, A. M.: Suspended sediment supply dominated by bank erosion in a low-gradient agricultural watershed, Wildcat Slough, Fisher, Illinois, United States, J. Soil Water Conserv., 70, 145-155, https://doi.org/10.2489/jswc.70.3.145, 2015.

Nikora, V., Larned, S., Nikora, N., Debnath, K., Cooper, G., and Reid, M.: Hydraulic Resistance due to Aquatic Vegetation in Small Streams: Field Study, J. Hydraul. Eng., 134, 1326-1332, https://doi.org/10.1061/(ASCE)07339429(2008)134:9(1326), 2008.

Peterson, E. W. and Benning, C.: Factors influencing nitrate within a low-gradient agricultural stream, Environ. Earth Sci., 68, 1233 1245, https://doi.org/10.1007/s12665-012-1821-x, 2013.
Pimentel, D., Harvey, C., Resosudarmo, P., Sinclair, K., Kurz, D., McNair, M., Crist, S., Shpritz, L., Fitton, L., Saffouri, R., and Blair, R.: Environmental and economic costs of soil erosion and conservation benefits, Science, 267, 1117-1123, https://doi.org/10.1126/science.267.5201.1117, 1995.

Seeger, M., Errea, M.-P., Beguerìa, S., Arnáez, J., Martì, C., and Garcìa-Ruiz, J.: Catchment soil moisture and rainfall characteristics as determinant factors for discharge/suspended sediment hysteretic loops in a small headwater catchment in the Spanish pyrenees, J. Hydrol., 288, 299-311, https://doi.org/10.1016/j.jhydrol.2003.10.012, 2004.

Shore, M., Jordan, P., Mellander, P.-E., Kelly-Quinn, M., and Melland, A. R.: An agricultural drainage channel classification system for phosphorus management, Agr. Ecosyst. Environ., 199, 207-215, https://doi.org/10.1016/j.agee.2014.09.003, 2015.

Stoate, C., Boatman, N., Borralho, R., Carvalho, C. R., Snoo, G. R. D., and Eden, P.: Ecological impacts of arable intensification in Europe, J. Environ. Manage., 63, 337-365, https://doi.org/10.1006/jema.2001.0473, 2001.

Vereecken, H., Baetens, J., Viaene, P., Mostaert, F., and Meire, P.: Ecological management of aquatic plants: effects in lowland streams, Hydrobiologia, 570, 205-210, https://doi.org/10.1007/s10750-006-0181-5, 2006.

Walling, D. E.: Tracing suspended sediment sources in catchments and river systems, Sci. Total Environ., 344, 159-184, https://doi.org/10.1016/j.scitotenv.2005.02.011, 2005.

Walling, D. E. and Amos, C. M.: Source, storage and mobilisation of fine sediment in a chalk stream system, Hydrol. Process., 13, 323-340, https://doi.org/10.1002/(SICI)10991085(19990228)13:3<323::AID-HYP741>3.0.CO;2-K, 1999.

Withers, P. J. A. and Jarvie, H. P.: Delivery and cycling of phosphorus in rivers: a review., Sci. Total Environ., 400, 379-95, https://doi.org/10.1016/j.scitotenv.2008.08.002, 2008.

Zumr, D. and Císlerová, M.: Soil moisture dynamics in levees during flood events - variably saturated approach, J. Hydrol. Hydromech., 58, 64-72, https://doi.org/10.2478/v10098-010-0007z, 2010

Zumr, D., Dostál, T., and Devátý, J.: Identification of prevailing storm runoff generation mechanisms in an intensively cultivated catchment, J. Hydrol. Hydromech., 63, 246-254, https://doi.org/10.1515/johh-2015-0022, 2015. 